\title{
STUDY OF GALL BLADDER STONES AS A NEW PIEZOELECTRIC SENSOR MATERIAL
}

\author{
V.R. Singh, Fellow-IEEE \\ National Physical Laboratory, New Delhi-110012, India, and \\ Professor, Korea University, Seoul/Jochiwon, South Korea) \\ Email: vrsingh@ieee.org, vrsinghdr@gmail.com
}

\begin{abstract}
Gall bladder stones are studied as new sensor materials for biomedical and other applications. The material samples have been examined the chemical composition by using an $X$-Ray diffractometry and $\alpha$-quartz is found to be present in the these stones which is responsible for piezoelectric property of such materials to develop new sensors.
\end{abstract}

\section{INTRODUCTION}

The gall bladder (GB) stones are layered crystalline composites. which have complex chemical composition. There is a large variation in the chemical composition due to diet, age and other climatic and environmental conditions. The GB stones occur in the gall bladder, and vary in size and shape, and become problem of discomfort and pain to the patients. Its removal is thus important. Such stones and other hard tissues have been studied for physical and electrical properties to use them in sensor applications [1-8].

As the GB stones are of heterogeneous structure, the X-ray technique is used for the analysis of the composition. More than one hundred GB stones collected from various local hospitals in Delhi was carried out in this laboratory. The main composition contents are apatite, ammonium magnesium phosphate, uric acid, brushite, crytine, etc. These have been studied [5-7] for various other characteristics also.

In the present study, gall bladder stones are studied as new piezoelectric materials. Electrical (resistivity), dielectric (dielectric constant, dissipation factor) and piezoelectric (charge and voltage constants) of solid GB stones are determined.

\section{METHODS AND MATERIALS}

The in vitro GB stone samples have been collected from local hospitals. The stones have been used in the measurements in the original solid form, after necessary shaping to size. Also, tablets have been made from powdered form, by using similar method as used for PZT discs [2]. The physical and electrical properties have been measured by using conventional equipment as used earlier in the basic sties to investigate the piezoelectric effect in the kidney stones $[1,2]$.
Samples on the X-ray analysis were prepared by crushing the stones to fine powder in an agate pestle and mortar. The circular cavity of the specimen holder was filled with the fine powder and was compressed with a glass slide using thumb pressure. The specimen holder was then inserted in the specimen-holder support of the diffractometer. A SIEMENS D-500 diffractometer was used to investigate the crystalline phases. Copper $\mathrm{K} \alpha \quad\left(\lambda=1.5418^{\circ} \mathrm{A}\right)$ radiation at $35 \mathrm{kV}$ and $12 \mathrm{~mA}$ was used. The diffractograms were taken by using scintillation counter as detector in conjunction with graphite monochrometer under the condition of scanning speed of $1^{\circ} / \mathrm{min}$ and range $2 \times 12^{2}$ counts $/ \mathrm{s}$.

The value of $d$ was recorded in different values of angle $\theta$ given by Bragg's Law, $\mathrm{n} \lambda=2 \mathrm{~d} \operatorname{Sin} \theta \mathrm{g}$, for $\lambda=1.5418^{\circ} \mathrm{A}$. The intensity of the diffracted beam was measured directly with the help of an electronic counter for different angular positions $[6,7]$.

\section{RESULTS AND DISCUSSIONS}

The average results for the dielectric constant, capacitance, resistivity, charge constant and voltage constant are given in Table I for over 100 samples, each of both types of tablets made from solid and powdered GB stones [1]. The dissipation factor and dielectric loss factor of the solid stone specimen are found to be higher than that for the powdered stone tablets. There was no piezoelectric effect before poling, as found by taking measurements on un poled samples. The results of $\mathrm{d}_{33}, \mathrm{~g}_{33}$, etc., demonstrate the property of piezoelectricity in GB stones and the results are given in Table I. The tablets with lower loss factor $(\tan \delta)$ and with relatively low value of $g_{z z}$ constant are suitable for piezoelectric devices. The curie temperature of the stone was found to be in the range of $235^{\circ} \mathrm{C}$. The dielectric loss factor was found to increase with the increase in frequency for all the stone tablets, which is in accordance with the behavior of soft materials. The charge constant of the stone discs as well as of tablets, drops and disappears after 
sometimes, due to weak piezoelectric behaviour, which is also true for quartz or for other biological materials $[1,2]$.

The piezoelectric effect was also studied with the help of $\mathrm{X}$-ray spectroscopy and X-ray fluorescence techniques. Alpha-quartz ( $\mathrm{SiO}_{2}$ ) was observed first time in the calculi. This property explains the piezoelectricity in the GB stones. The piezoelectric behavior would further assist in faster disruption of stones $[3,4]$. Also, due to the presence of alpha-quartz or piezoelectric behavior of stress-generated electric potential was observed. Kidney stones having more percentage of alpha-quartz have more piezoelectric behavior. The results obtained in the present investigation would assist in the design of focused ultrasonic lithotripter, which is being developed at NPL. Thus, the presence of alpha-quartz in the GB stones is investigated first time and the GB stones become a new source of piezoelectricity. New types of piezoelectric sensors by using GB stone material have been initially developed.

In the present investigation, calcium oxalate was identified in two forms: one calcium oxalate monohydrate (whewellite) and the other calcium oxalate dehydrate (weddellite), the former being formed very frequently. The other crystalline components identified were magnesium potassium phosphate, calcium carbonate (calcite) magnesium hydrogen phosphate hydrate, calcium phosphate (hydroxyl-apatite), magnesium ammonium phosphate (struvite), uric acid and silicon oxide (quartz). Out of the 100 samples, three samples contained pure calcium oxalate monohydrate and one had maximum uric acid. Two stones were found to have both calcium oxalate monohydrate and calcium oxalate dehydrate, and in other two stones, uric acid was identified in addition to calcium oxalate monohydrate [7]. The $\alpha$-quartz is observed for the first time in the GB stones. Although the percentage of $\alpha$-quartz is less, but it is also in important constituent in the GB stones [7-8].

\section{CONCLUSION}

The gall bladder stones, in vitro, have been studied and used as piezoelectric material for the development of new types of sensors for use in biomedical instrumentation systems. Both diagnostic and therapeutic sensors with better stability and reliable output, as compared to that of conventional ultrasonic sensors, may be developed, with newly developed GB material, which is low cost and easily available, if planned properly.

\section{REFERENCES}

[1] V.R.Singh, R.Agarwl and V.Singh, "Piezoelectric effect in renal calculi", IEEE Trans on Biomed Engg,Vol 38 (2), pp 218 219, Feb. 1991

[2] V.R.Singh, A.Ahmed and S.Yadav, "Electrical and mechanical properties onf animal bone in vitro', J. Instn Engrs, vol. 68, pp. 43-47, 1988.

[3] V.R Singh, "Portable ultrasonic lithotripters", Proc. IEEEEMBS Asia-Pacific Conf on BioMed Engg, Hangzhou (China), Sept. 26-28, p. 883, 2000.

[4] V.R. Singh, "Mobile ultrasonic lithotripters: evolution in lithotripters", Proc. Nat Conf. On Biomed Engg, Roorkee, pp. 387-398, April 21-22, 2000.

[5] V.R. Singh and R. Agarwal, "A study of ultrasonic characteristics of renal calculi, in vitro", JASA, 83, pp 962-963, 1989.

[6] S. Yadav and S. Singhal, V.R.Singh and K.C. Nagpal, "Study on variation of ultrasonic propagation parameters of bone by x-ray diffraction technique", Appl. Acoustics, 26:45-56; 1989.

[7] R.Agarwal, V.R.Singh, U.Dhawan, V.Singh, K.C. Nagpal and S.P.Sud, "Investigation of renal calculi as piezoelectric materials by using X-ray diffraction technique", Bio-Med Materiala and Engrg, vol. 1, pp. 149-154, 1991.

[8] V.R. Singh and R. Agarwal, "Ultrasonic studies of gall bladder stones", Ultrasonics, vol. 27, pp. 114-115, 1989.

TABLE 1: PIEZOELECTRIC CONSTANTS OF IN VITRO GALL BLADDER STONES

\begin{tabular}{|c|c|c|c|c|c|c|c|}
\hline Sr. No. & $\begin{array}{l}\text { Tablet prepared from } \\
\text { stones }\end{array}$ & $\begin{array}{l}\text { Capacitan } \\
\text { ce pF }\end{array}$ & $\begin{array}{l}\text { Dielectric loss } \\
\text { factor } \tan \delta\end{array}$ & $\begin{array}{l}\text { Dielectric } \\
\text { constant } \\
\mathrm{K}_{3}{ }^{\mathrm{T}}\end{array}$ & $\begin{array}{l}\text { Resistivity } \\
10^{8} \text { ohm-cm }\end{array}$ & $\begin{array}{l}\text { Charge constant } \\
10^{-12} \mathrm{C} / \mathrm{N}\end{array}$ & $\begin{array}{l}\text { Voltage constant } \\
10^{-3} \mathrm{Vm} / \mathrm{N}\end{array}$ \\
\hline 1. & $\begin{array}{l}\text { Solid GB Stones } \\
\text { (a) minimum values } \\
\text { (b) maximum values }\end{array}$ & $\begin{array}{l}10.5 \\
14.0\end{array}$ & $\begin{array}{l}0.0230 \\
0.0293\end{array}$ & $\begin{array}{l}37.31 \\
39.62\end{array}$ & $\begin{array}{l}16.0 \\
25.0\end{array}$ & $\begin{array}{l}27.0 \\
27.0\end{array}$ & $\begin{array}{l}96.07 \\
99.86\end{array}$ \\
\hline & (c) Average values & 12.25 & 0.0262 & 38.42 & 20.5 & 27.0 & 97.44 \\
\hline 2. & $\begin{array}{l}\text { Powdered GB Stones } \\
\text { (a) minimum values } \\
\text { (b) maximum values }\end{array}$ & $\begin{array}{l}13.6 \\
19.8\end{array}$ & $\begin{array}{l}0.022 \\
0.036\end{array}$ & $\begin{array}{l}16.80 \\
18.64\end{array}$ & $\begin{array}{l}12.0 \\
19.0\end{array}$ & $\begin{array}{l}31.0 \\
39.0\end{array}$ & $\begin{array}{l}17.36 \\
28.58\end{array}$ \\
\hline & (c) Average values & 16.7 & 0.029 & 17.72 & 15.50 & 35.00 & 22.97 \\
\hline
\end{tabular}

